\title{
Technology Intervention through Cluster Frontline Demonstration in Mustard Crop in South - Western Region of Haryana
}

\author{
Yogita Bali $^{1 *}$, Gulab Singh $^{2}, \mathrm{Meenu}^{3}$ and Murari Lal ${ }^{4}$ \\ ${ }^{1}$ Department of Agronomy, ${ }^{2}$ Department of Agril. Economics, \\ ${ }^{3}$ Department of Entomologist, ${ }^{4}$ Department of Horticulture, Krishi Vigyan Kendra, \\ Bhiwani-127021, Haryana, India \\ *Corresponding author
}

\section{A B S T R A C T}

\section{Keywords}

Cluster Frontline

demonstration,

Economic, Impact,

Intervention,

Mustard and

Technology

Article Info

Accepted:

12 March 2021

Available Online:

10 April 2021
Cluster frontline Demonstrations (CFLD) on mustard were conducted by the KVK, Bhiwani district in Haryana during two consecutive years i.e. 2018-19 \& 2019-20. Improved technology of crop production were demonstrated at farmer's field with check varieties (Farmer's Practice) in district Bhiwani, conducted 113 demonstrations on mustard variety - RH 749, RH 0725 during two consecutive years. The thrust area \& gap were identified after discussion with farmer on production technology of oilseed crop. Adoption of improved practice in demonstration, increased yield of mustard by with $9.17 \%$.over farmer practices. The average Yield of mustard in two consecutive years in demonstration plot was $22.05 \mathrm{q} / \mathrm{ha}$. The gap in yield were observed between demonstrated plot and farmer practice on part of technology intervention, its impact and economical impact were analyzed for assessment of cluster front line demonstration on mustard crop. The results of two years study revealed that the yield under demonstration plots was $22.05 \mathrm{q} / \mathrm{ha}$ as compared to 19.65 $\mathrm{q} /$ ha in farmer practices plots. Demonstration plot came out with an average Gross \& Net return of Rs. 88200 and Rs. 61918/ha, which were higher than those obtained in local check plots. The B:C ratio in demonstrated plot came out with 3.35, which were recorded higher than in local check plot during the years of experimentation. Thus the results clearly indicate the impact of improved technology on Cluster Front Line Demonstration over the existing practices.

\section{Introduction}

Cluster frontline demonstrations on mustard were conducted under the guidance of scientist at farmer's field with maximum use of resources available at field with improved technology to get maximum returns. In India, rape seed mustard is an important source of edible oil followed by ground nut (Panday et al., 1999). It is now widely accepted fact that training to farmers and farm women increases the technical knowledge regarding package of 
practices. KVKs are playing a vital role across the farming community in imparting knowledge in distinguish field also. The main objective of Cluster Front-Line Demonstrations is to demonstrate newly varieties and its management practices in the farmers' field under different farming situations with field constraints. Cluster Frontline Demonstrations are conducted in a block of one or two in order to have better impact of the demonstrated technologies on the farmers and field level extension functionaries. To exhibit the importance of improved practices in enhancing yield of mustard crop assess with adoption level of improved mustard production technologies by beneficiary farmers in comparison to nonbeneficiary farmers through cluster front line demonstration.

\section{Materials and Methods}

Cluster frontline demonstration on mustard were conducted at farmer's field during Rabi seasons from 2018 to 2020. The demonstrations were conducted in three cluster in district Bhiwani in two years. Mustard demonstration were conducted in 30 and 60 ha in Rabi season during $2018-19$ and 2019-20 respectively. The group of 38 and 75 farmers were selected on the basis of information collected in survey which was conducted before laying out of demonstration to know the technology adoption gaps, where demonstration is to be conducted.

The improved practices of mustard production were followed in demonstration plot. The improved Package of practices followed by farmers under CFLD includes use of quality seed (RH-749 \& RH-725), Seed treatment (bavistin2 $\mathrm{gm} / \mathrm{kg}$ ) Time of sowing last week of September to 20th October. Method of sowing $30 \mathrm{~cm}$ (row to row), $15-20 \mathrm{~cm}$ (plant to plant) and sowing method- in line, Fertilizer management 120: 100: 30 (N:P:S) kg/ha,
Weed management Pre-emergence application of Pendimethalin 30 EC 3.3 1/ha followed by manual weeding at 30 days after sowing, Water management -Light irrigation before flowering and after pod formation (if no rainfall) Plant protection (Need based application). Plot size for demonstration was kept 0.4 ha. The yield and returns of demonstration plots were compared with local check yield and returns were calculated in the way suggested by Yadav et al., (1999). The following formula was used for the calculation of benefit: cost ratio.

Benefit : cost ratio

Average gross/returns (Rs./ha)

$=$

Average cost of cultivation (Rs./ha)

\section{Plant height (cm)}

Plant height were observed randomly in the field and measured at time of maturity with the help of meter scale from soil surface to the tip of plant.

\section{No. of branches per plant}

The no. of primary and secondary branches were counted for 10 plants per plot randomly selected in the cluster. The observation on no. of branches was recorded at the time of siliqua formation.

\section{Yield attributing character}

\section{No. of siliquae per plant}

Total no. of siliquae counted on randomly selected plant and average were calculated.

\section{Length of siliqua (cm)}

Ten siliquae were selected from randomly selected plot of the demonstration. The length was measured and average was drawn. 


\section{No. of seed per siliqua}

No. of siliquae were recorded at time of maturity by counting the no. of seeds of 10 selected siliquae from randomly selected 10 plants and average were drawn.

\section{Seed yield (q/ha)}

The final seed yield was recorded in $\mathrm{kg}$ from the individual plot after harvested and threshed. The yield finally converted into q/ha.

\section{Biological Yield (q/ha)}

Above the ground parts of plant was harvested per plot after maturity, represent the biological yield, it was calculated as

$$
\begin{aligned}
& \text { Harvest Index \% } \\
& \text { Grain yield } \\
& \text { = -------X100 } \\
& \text { Biological Yield }
\end{aligned}
$$

\section{Results and Discussion}

Data presented in (table 1) on the effect of improved practices on yield. By the adoption of improved technology in demonstration plot increased yield during respective years. The improved practice includes improved varieties. Seed treatment, spacing, recommended dose of fertilizer, weed control and plant protection measure. The average yield of mustard in two years was $22.05 \mathrm{q} / \mathrm{ha}$ where as $19.65 \mathrm{q} / \mathrm{ha}$ in local check plot (Table 1). Thus increase in seed yield of mustard in demonstration plot was $9.17 \%$. The results are in consance with Chaudhary et al., 2018.

In (Table 2) effect of improved practice on returns were calculated and founded that both gross and net returns in demonstration plot were higher than that of farmer's practice. Av. gross and net returns obtained from demonstration plot were Rs. 88200 \& Rs.61918 /ha (Table-2) is more than the farmer's practice i.e. Rs. 79087 \& Rs. 54592 during the years respectively. The results are in line with Dhillon et al., 2020.

\section{Plant height (cm)}

In Table 3 plant height increase with the time period which is directly proportional to the age of crop. It is also significantly influence by the doses of nutrient and environment factor. Varieties had significant variation on plant height at the maturity stage i.e. pod formation, plant height of RH- 0725 were 7.5 significantly more than the RH 749 and farmer practice. It was quit evident from data that higher plant height was obtained in RH- 0725 at siliquae formation stage.

\section{No. of branches}

In table 3 the no. of siliquae significantly affected with no. of branches per plant and also depend upon crop growing environment. Among the varieties RH- 0725 \& RH 0749 were significantly superior over the RH- 0749 $\&$ farmer's practice during the crop growth period.

\section{Yield attributes}

\section{No. of siliquae per plant}

In table 4 Maximum no. of siliquae per plant was recorded in RH 0725 (397.5) followed by RH 0749 (355). Than farmer practice (317.5). It was noticed that siliquae per plant was significantly affected by the sowing time. 
Table.1 Performance of CFLD on Mustard at farmer's field at Bhiwani district of Haryana

\begin{tabular}{|c|c|c|c|c|c|c|c|}
\hline $\begin{array}{l}\text { Sr } \\
\text { no. }\end{array}$ & Crop & Season & $\begin{array}{c}\text { No. of } \\
\text { demonstration }\end{array}$ & $\begin{array}{c}\text { Area } \\
\text { (ha) }\end{array}$ & \multicolumn{2}{|c|}{ Av. Yield (q/ha) } & \multirow[t]{2}{*}{$\begin{array}{c}\text { Yield } \\
\text { Increase } \\
\%\end{array}$} \\
\hline & & & & & $\begin{array}{c}\text { Improved } \\
\text { practice }\end{array}$ & $\begin{array}{l}\text { Farmer's } \\
\text { Practice }\end{array}$ & \\
\hline 1 & $\begin{array}{c}\text { Mustard } \\
\text { RH- } 0749\end{array}$ & $\begin{array}{c}\text { Rabi } \\
2018-19\end{array}$ & 38 & 30 & 21.6 & 19.8 & 8.33 \\
\hline \multirow[t]{2}{*}{2} & $\begin{array}{l}\text { Mustard } \\
\text { RH-0725 }\end{array}$ & $\begin{array}{c}\text { Rabi } \\
\text { 2019-20 }\end{array}$ & 75 & 60 & 22.5 & 20.25 & 10.00 \\
\hline & \multicolumn{2}{|c|}{ Average } & 113 & 90 & 22.05 & 19.65 & 9.17 \\
\hline
\end{tabular}

Table.2 Economic analysis of CFLD at farmer's field in Bhiwani district of Haryana

\begin{tabular}{|c|c|c|c|c|c|c|c|c|}
\hline season & \multicolumn{2}{|c|}{$\begin{array}{c}\text { Av. cost of } \\
\text { cultivation (Rs/ha) }\end{array}$} & \multicolumn{2}{c|}{$\begin{array}{c}\text { Gross returns } \\
\text { (Rs./ha) }\end{array}$} & \multicolumn{2}{c|}{$\begin{array}{c}\text { Net returns } \\
\text { (Rs./Ha) }\end{array}$} & \multicolumn{2}{|c|}{ B:C ratio } \\
\hline & IP & FP & IP & FP & IP & FP & IP & FP \\
\hline Rabi 2018 & 26250 & 24340 & 86400 & 79200 & 60150 & 54860 & 3.27 & 3.25 \\
\hline Rabi 2019 & 26315 & 24650 & 90000 & 78975 & 63685 & 54325 & 3.42 & 3.20 \\
\hline Average & & & 88200 & 79087 & 61918 & 54592 & 3.35 & 3.23 \\
\hline
\end{tabular}

Table.3 Primary and secondary branches par plant along with plant height of mustard varieties.

\begin{tabular}{|c|c|c|c|c|}
\hline Sr.no & varieties & $\begin{array}{c}\text { Primary branches/ } \\
\text { Plant }\end{array}$ & Sec. branches/Plant & $\begin{array}{c}\text { Avg.Plant height } \\
\text { (cm) }\end{array}$ \\
\hline $\mathbf{1}$ & RH 0725 & 7 & 52 & 7.5 \\
\hline $\mathbf{2}$ & RH 0749 & 4.5 & 41 & 5.5 \\
\hline $\mathbf{3}$ & $\begin{array}{c}\text { Farmer } \\
\text { practice }\end{array}$ & 5.5 & 39 & 4.7 \\
\hline
\end{tabular}

Table.4 Yield attributes of mustard varieties during cropping season

\begin{tabular}{|c|c|c|c|c|}
\hline Sr no. & Varities & $\begin{array}{c}\text { No. of siliquae } \\
\text { /plant }\end{array}$ & Length of siliqua (cm) & No. of seeds / siliqua \\
\hline $\mathbf{1}$ & RH 0725 & 397.5 & 5.65 & 15 \\
\hline $\mathbf{2}$ & RH 0749 & 355 & 5.2 & 13 \\
\hline $\mathbf{3}$ & $\begin{array}{c}\text { Farmer } \\
\text { practice }\end{array}$ & 317.5 & 4.9 & 13 \\
\hline
\end{tabular}




\section{Length of siliquae (cm)}

According to table 4 average Length of siliquae of RH $0725(5.65 \mathrm{~cm})$ was recorded more than RH $0749(5.2 \mathrm{~cm})$ and farmer practice $(4.9 \mathrm{~cm})$.

Length of siliquae was measured in randomly selected plot with randomly selected plants at demonstrated and farmer's field during 201819 and 2019-20

\section{No. of seeds per siliqua}

No. of seed per siliquae were recorded maximum 15 in RH 0725 followed by the RH 0749 (13) and farmer practice (13) at harvest by counting no. of seed per siliqua from randomly selected siliqua from ten plants of each plot.

\section{Seed Yield (q/ha)}

The seed yield (q/ha) was recorded and found that it was significantly affected by sowing time and environment. The maximum yield was recorded 22.05 with RH 0725 followed by RH 0749 \& farmer practice.

As the demonstration conducted through cluster frontline demonstration is an effective tool in horizontal spread of technology, knowledge and skill among the farmers and also help to create awareness and motivated the other farmer to adopt the improved package and practice.

The higher $\mathrm{B}: \mathrm{C}$ ratio in demonstration plot could be attributed to higher yield of demonstration plot than farmer's practice and also found that gaining knowledge regarding improved technology through training, demonstration, group meeting, mla, field days, $\&$ exposure visit were prove very useful to disseminate technology from Lab to field.

\section{References}

Choudhary, R. P., Choudhary, G. K., Prasad, R. (2018). Impact Assessment of Front Line Demonstration on Muatard Crop. Int. J. Curr. Microbiol. App. Sci.7: 4737-4742.

Dhillon, A., Kumar, R., Bali, Y. and Shivran, A. 2020. Increasing productivity and profitability of pulses through cluster frontline demonstration in Mahendergarh district of Haryana. Crop Res.55(1\&2):14-16.

Jaiswal P., Mishra A. N., Singh A. K, Mishra S.R., Kumar R., Singh G., and Sharma K.D, studies on mustard (Brassica juncea $\mathrm{L}$.) varities under various crop growing environment in eastern plain zone. Int. J.chemical studies 2019;7(4):1959-1963

Kumar, S. and Kispotta, W. (2017). Impact of frontline demonstrations on Indian mustard through improved technology. Res. Crops $18: 789-93$

Meena S. R. and Sharma Y. K. 2019. Extent of Adoption and Adoption Gaps among-st the Mustard Growers (B. F. \& NB. F.) regarding Recommended Mustard Production Technology. Int.J.Curr.Microbiol.App.Sci. $\quad 8(09)$ : 1718-1735

Panday. I. D, Basudeo Singh and J. N. Sachan. 1999. Brassica Hybrid research in India: status and prospects. Proceedings of the tenth international rape seed congress. Canberra, Australia.

Patel, M., Prajapati, K P., Khule, A A., and Patel, L.P. Combining ability analysis for seed yield and its attributes in Indian mustard [Brassica juncea (L.) Czern and Coss] J. Oilseeds Res., 31(1) : 70-72, June, 2014

Patil S. S, Mahale M. M, Chavan S. S. Impact of Frontline Demonstrations (FLDs) on Oilseed Crops in South Konkan 
Coastal Zone of Maharashtra. Curr Agri Res 2018;6(3).

Vijaya Lakshmi, D., P. Vijay Kumar and C. Padma Veni. Impact of Cluster Frontline Demonstrations to Transfer of Technologies In Pulse Production Under NFSM. Bull. Env. Pharmacol.
Life Sci., Vol 6 Special issue 1, 2017: 418-421

Yadav,Y. P., Singh, B. and Kumar, A.(1999). Evaluation of frontline demonstration trails on mustard in south-western region of Haryana. Haryana aric.Univ.J.Res.29: 39-42.

\section{How to cite this article:}

Yogita Bali, Gulab Singh, Meenu and Murari Lal. 2021. Technology Intervention through Cluster Frontline Demonstration in Mustard Crop in South -Western Region of Haryana. Int.J.Curr.Microbiol.App.Sci. 10(04): 212-217. doi: https://doi.org/10.20546/ijcmas.2021.1004.020 